\title{
Uji Tetrazolium pada Benih Kecipir (Psophocarpus tetragonolobus (L.) DC.) sebagai Tolok Ukur Viabilitas
}

\section{Tetrazolium Test on Winged Bean Seed (Psophocarpus tetragonolobus (L.) DC.) As Standard Measuring Viability}

\section{Lia Irma Fatmawati, Tatiek Kartika Suharsi" dan Abdul Qadir}

\author{
Departemen Agronomi dan Hortikultura, Fakultas Pertanian, Institut Pertanian Bogor (Bogor Agriculture \\ University) Jl. Meranti, Kampus IPB Darmaga, Bogor 16680, Indonesia \\ Telp. \& Faks. 62-251-8629353 e-mail : agronipb@indo.net.id \\ *Penulis untuk korespondensi : tsuharsi@yahoo.co.id
}

Disetujui 14 Mei 2018 / Published online 21 Mei 2018

\begin{abstract}
The availability of quality seeds and winged bean seed quality information is still limited. This can be overcome with the process of testing the quality of seed. The purpose of this research was to obtain pretreatment procedure test suite for testing tetrazolium winged bean seeds, obtain the appropriate method for rapid aging winged bean seed, obtain staining pattern in the embryo as an indirect indication to detect the winged bean seed viability. Research conducted at the Laboratory of Seed Science and Technology IPB from August to December 2016. The first experiment obtained effective aquades soaking time was 24 hours, obtained effective tetrazolium concentration was $0,3 \%$, obtained effective tetrazolium soaking time was two hours. The second experiment obtained rapid aging methods, that was chemically and have five times the scourging that produces gradual viability ie 0x5, 2x5, 4x5, 6x5, and 8x5 minutes. The third experiment cannot used to detect winged bean seed viability because pattern criteria which are made is too narrow.
\end{abstract}

Keywords: staining patterns embrio, gradual viability, seed rapid aging, tetrazolium concentration

\begin{abstract}
ABSTRAK
Ketersediaan benih bermutu serta informasi mutu benih kecipir masih terbatas. Hal tersebut bisa diatasi melalui proses pengujian mutu benih. Tujuan penelitian ini adalah memperoleh prosedur perlakuan pra test yang sesuai untuk pengujian tetrazolium benih kecipir, memperoleh metode pengusangan yang sesuai untuk benih kecipir, memperoleh pola pewarnaan pada embrio sebagai indikasi tidak langsung untuk mendeteksi viabilitas benih kecipir. Penelitian dilaksanakan di Laboratorium Ilmu dan Teknologi Benih IPB pada bulan Agustus sampai Desember 2016. Percobaan pertama memperoleh waktu perendaman aquades yang efektif pada benih kecipir yaitu 24 jam, memperoleh konsentrasi tetrazolium yang efektif yaitu 0,3\%, memperoleh waktu perendaman tetrazolium yang efektif yaitu dua jam. Percobaan kedua memperoleh metode pengusangan, yaitu pengusangan secara kimia dan dipilih 5 waktu penderaan yang menghasilkan viabilitas secara gradual yaitu $0 \times 5,2 \times 5,4 \times 5,6 \times 5$, dan $8 \times 5$ menit. Percobaan ketiga pola pewarnaan pada embrio benih kecipir belum bisa digunakan untuk mengevaluasi viabilitas benih kecipir karena diduga kriteria pola yang dibuat terlalu sempit.
\end{abstract}

Kata kunci : embrio, konsentrasi tetrazolium, pengusangan benih, pola pewarnaan embrio, viabilitas gradual 


\section{PENDAHULUAN}

Kecipir (Psophocarpus tetragonolobus (L.) DC.) merupakan tanaman jenis legum yang sudah lama dikenal di Indonesia. Umumnya tanaman kecipir tumbuh di pekarangan, pinggir pematang, dan tegalan. Kecipir muda sering dimanfaatkan oleh masyarakat untuk sayur. Kecipir tidak hanya dimanfaatkan polong mudanya saja untuk dijadikan sebagai sayur, polong tua yang bijinya sudah tua juga berpotensi dimanfaatkan sebagai bahan olahan makanan lain seperti tempe, tepung, tahu, dan sebagainya. Menurut Handayani (2013) biji kecipir tua mengandung protein sebesar $33,3-38,3 \%$ yang hampir sama dengan kandungan protein biji kedelai sebesar 39,8-41,8\% sehingga bisa menjadi alternatif pendamping kedelai sebagai bahan baku olahan tempe, tahu, dan sebagainya. Tempat tumbuh kecipir sangat luas dan potensial dikembangkan di berbagai tempat di daerah tropis (Krisnawati, 2010). Hal ini memberikan peluang yang tinggi bagi kecipir untuk dibudidayakan dan dikembangkan sebagai alternatif sumber pangan dan protein nabati.

Kendala saat ini yang dihadapi untuk pengembangan kecipir adalah ketersediaan benih bermutu yang terbatas, informasi mutu benih kecipir yang belum memadai, serta penelitian benih kecipir yang masih terbatas. Upaya untuk mendapatkan benih yang bermutu serta informasi mutu suatu benih yaitu harus melewati proses pengujian mutu benih. Pengujian mutu benih terdiri atas metode pengujian dan indikasi yang dihasilkan. Metode pengujian terdiri atas metode langsung dan metode tidak langsung. Indikasi yang dihasilkan terdiri atas indikasi langsung dan tidak langsung. Indikasi langsung adalah pengujian yang menghasilkan kecambah, sedangkan indikasi tidak langsung adalah pengujian yang tidak menghasilkan kecambah (Widajati et al., 2013). Menurut Copeland dan McDonald (2001) metode langsung indikasi langsung seperti uji daya berkecambah mengetahui persentase benih yang berkecambah normal, sedangkan metode langsung indikasi tidak langsung seperti uji tetrazolium untuk mengetahui persentase benih hidup, benih tidak hidup, serta benih dorman.

Benih kecipir mempunyai struktur kulit yang keras (Handayani, 2013). Hal tersebut menandakan bahwa kecipir mempunyai tingkat dormansi yang tinggi yang menyebabkan benih sulit berkecambah dan sulit dievaluasi viabilitasnya. Perlu adanya suatu metode untuk mengevaluasi viabilitas secara cepat dan tepat. Metode pengujian benih dengan menggunakan uji tetrazolium (Copeland dan McDonald, 2001). Uji tetrazolium jarang dilakukan oleh analis benih karena bukan merupakan pengujian rutin. Menurut Copeland dan McDonald (2001) uji tetrazolium pada masa yang akan datang merupakan pengujian standar yang digunakan oleh analis benih untuk memberikan informasi viabilitas suatu benih secara cepat.

Uji tetrazolium merupakan uji viabilitas benih untuk mendeteksi suatu benih termasuk benih hidup atau benih mati dengan berbasis respirasi dengan bantuan enzim dehidrogenase (Copeland dan McDonald, 2001). Aktivitas enzim dehidrogenase akan melepaskan ion $\mathrm{H}+$ dan bereaksi dengan larutan tetrazolium sehingga membentuk zat trifenil formazan yang berwarna merah, stabil dan tidak larut air (Copeland dan McDonald, 2001). Letak dan ukuran daerah yang terwarnai serta intensitas pewarnaan disebut pola topografi, menentukan klasifikasi benih hidup atau mati (ISTA, 2014). Tujuan dari penelitian ini yaitu memperoleh prosedur perlakuan pra test yang sesuai untuk pengujian tetrazolium benih kecipir, mengetahui metode pengusangan yang sesuai untuk benih kecipir serta memperoleh pola pewarnaan pada embrio sebagai indikasi tidak langsung untuk mendeteksi viabilitas benih kecipir

\section{METODE}

Penelitian dilaksanakan di Laboratorium Ilmu dan Teknologi Benih Departemen Agronomi dan Hortikultura, Fakultas Pertanian, Institut Pertanian Bogor. Penelitian dilaksanakan mulai bulan Agustus 2016 sampai bulan Desember 2016.

Bahan yang digunakan yaitu benih kecipir aksesi Tajur yang dipanen pada bulan Juni 2016. Bahan lain yang digunakan antara lain garam tetrazolium, larutan buffer, alkohol 96\%, kertas cd buram, plastik, label, kertas aluminium foil, aquades. Alat-alat yang digunakan yaitu glass jar, $\mathrm{pH}$ meter, timbangan analitik, kamera, inkubator, alat pengecambah benih tipe IPB 72-1 (APB IPB 72-1), alat pengepres kertas tipe IPB 75-1, oven, desikator, alat pengusangan cepat APC IPB 77-1 MM, alat pengusangan cepat APC IPB 77-1 MMM, dan alat laboratorium lainnya.

Rancangan percobaan yang digunakan pada percobaan pengusangan benih kecipir metode fisik dan kimia adalah rancangan acak lengkap (RAL) dengan satu faktor yaitu pengusangan. Rancangan percobaan yang digunakan pada pengujian pola pewarnaan pada benih kecipir 
adalah rancangan acak lengkap (RAL) dengan satu faktor yaitu pengusangan.

Percobaan pra test diawali dengan optimasi perendaman aquades (imbibisi) sebelum perendaman tetrazolium. Imbibisi dilakukan dengan merendam benih kecipir dalam aquades dengan waktu perendaman (12 jam, 24 jam, dan 36 jam). Benih kemudian dikelupas testanya sebelum direndam ke dalam larutan tetrazolium. Lama perendaman yang terpilih, dipilih berdasarkan benih yang paling mudah dan paling banyak yang dapat dikelupas. Optimasi konsentrasi dan perendaman tetrazolium dilakukan setelah lama perendaman aquades terpilih. Benih yang telah dikelupas kemudian direndam dalam tetrazolium dengan konsentrasi $(0,1 \%, 0,2 \%$, dan $0,3 \%)$ selama satu jam dan dua jam. Benih tersebut direndam dengan suhu $40^{\circ} \mathrm{C}$ dalam tabung gelas yang dilapisi kertas aluminium foil dan disimpan dalam inkubator/oven. Benih kemudian dicuci dengan aquades dan diamati. Peubah yang diamati adalah banyaknya benih yang dapat dikelupas, intensitas warna yang paling baik untuk pengujian tetrazolium, berupa benih berwarna putih, merah muda, merah cerah, dan merah gelap.

Percobaan pengusangan yang dilakukan terdiri atas dua metode, yaitu secara fisik dan kimia. Pengusangan secara fisik menggunakan tingkat pengusangan yang didera suhu dan $\mathrm{RH}$ tinggi $\left(52^{\circ} \mathrm{C}\right.$ dan $\left.98 \%\right)$ dengan alat pengusangan MPC 77-1 MMM. Penderaan dilakukan sebanyak 10 taraf, yaitu $0,1 \times 3,2 \times 3,3 \times 3,4 \times 3,5 \times 3,6 \times 3$, $7 \times 3,8 \times 3$, dan $9 \times 3$ menit. Pengusangan secara kimia menggunakan tingkat pengusangan yang didera etanol 96\% dengan alat pengusangan MPC 77-1 MM. Penderaan dilakukan sebanyak 10 taraf, yaitu $0,1 \times 5,2 \times 5,3 \times 5,4 \times 5,5 \times 5,6 \times 5,7 \times 5$, $8 \times 5$, dan $9 \times 5$ menit. Benih sebelum didera diimbibisi terlebih dahulu menggunakan aquades. Imbibisi dilakukan dengan waktu sesuai pada hasil percobaan pra test. Benih kemudian dikecambahkan. Peubah yang diamati adalah kadar air (KA), daya berkecambah (DB), indeks vigor (IV), potensi tumbuh maksimum (PTM), dan berat kering kecambah normal (BKKN). Metode pengusangan yang terpilih kemudian dipilih lima taraf untuk melakukan percobaan selanjutnya.

Pembuatan pola diawali dengan membuat larutan tetrazolium. Langkah pertama, larutan tetrazolium dibuat dengan konsentrasi yang terpilih pada percobaan pra test. Larutan kemudian disimpan dalam wadah yang kedap cahaya (Dina et al., 2007). Benih yang akan diwarnai tetrazolium dan telah didera sesuai dengan metode pada percobaan pengusangan terlebih dahulu diimbibisi dengan aquades sesuai pada percobaan pra test. Benih kemudian direndam dalam larutan tetrazolium dengan konsentrasi dan lama perendaman tetrazolium sesuai dengan hasil percobaan pra test pada suhu $40^{\circ} \mathrm{C}$. Benih yang sudah direndam dengan larutan tetrazolium kemudian dicuci dengan air mengalir sampai bersih. Benih kemudian direndam dalam air bersih dan dilakukan pengamatan. Pengamatan dilakukan dengan mengelompokkan benih sesuai dengan pola topografi pewarnaan yang terbentuk. Benih satu persatu diamati kemudian diambil gambarnya. Pola pewarnaan dibuat sebanyak tiga pola, yaitu pola 1, pola 2 , dan pola 3 . Standar pola pewarnaan dibuat untuk membedakan antara benih yang berpotensi tumbuh menjadi normal kuat, normal, abnormal, dan mati.

Pengujian pola terdiri atas dua pengujian, yaitu pengujian viabilitas indikasi langsung dan tidak langsung. Pengujian viabilitas indikasi langsung merupakan pengujian yang digunakan sebagai pembanding pada pengujian viabilitas dengan indikasi tidak langsung (tetrazolium). Pengujian viabilitas indikasi langsung yaitu dengan mendera benih kecipir menjadi lima lot dengan alat MPC IPB 77-1 seperti pada percobaan pengusangan. Benih kemudian dikecambahkan. Benih kecipir tersebut kemudian diuji dengan larutan tetrazolium. Pengujian dan pengamatan dilakukan sesuai dengan tahap pembuatan pola. Pengamatan pada pengujian viabilitas indikasi langsung menggunakan tolok ukur potensi tumbuh maksimum (PTM), daya berkecambah (DB) dan indeks vigor (IV). Pengujian pada pengujian viabilitas indikasi tidak langsung menggunakan tolok ukur yang sama dengan pengujian viabilitas indikasi langsung, yaitu PTM, DB, dan IV.

Data pada percobaan kedua dianalisis dengan uji F. Jika terdapat pengaruh yang nyata dalam perlakuan maka dilakukan uji nilai tengah menggunakan uji DMRT pada taraf $\alpha$ 5\%. Analisis data pada percobaan ketiga menggunakan analisis regresi sederhana dan analisis korelasi sederhana. Pendekatan ini bertujuan untuk mengetahui dan membandingkan hubungan antara peubah pola pewarnaan tetrazolium dengan peubah tolok ukur fisiologis (Gomez dan Gomez, 1995).

\section{HASIL DAN PEMBAHASAN}

\section{Kondisi Umum Benih Kecipir}

Benih kecipir yang digunakan adalah benih aksesi Tajur yang berasal dari penanaman di Desa Tajur, Kabupaten Bogor, Jawa Barat. Benih yang digunakan adalah benih hasil panen pada 
bulan Juni tahun 2016. Benih dipanen dalam bentuk polong kering kemudian dijemur selama dua hari. Polong setelah dikeringkan kemudian dikupas, diambil bijinya, dan dipisahkan dari kotoran secara manual. Benih kecipir merupakan benih dikotil dengan struktur seperti pada Gambar
1. Benih yang telah dipilah ditentukan kadar air dan daya berkecambah awalnya sebelum disimpan dalam ruang peyimpanan benih. Benih mempunyai kadar air awal $14,75 \%$, daya berkecambah awal yaitu $65,33 \%$.

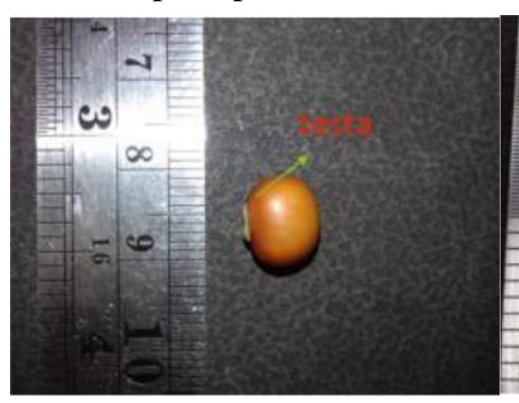

(a)

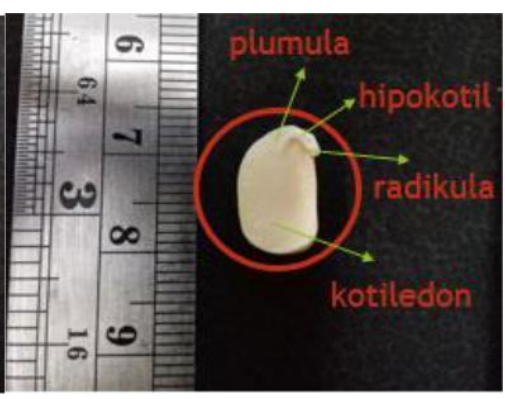

(b)

Gambar 1. Struktur benih kecipir (a) struktur benih belum terkelupas, (b) struktur benih setelah terkelupas

\section{Percobaan Pra Test}

Tabel 1 menunjukkan bahwa rata-rata benih yang dapat dikelupas terbanyak pada perendaman selama 36 jam. Meskipun terbanyak, benih banyak yang pecah dan keluar radikula namun tidak seluruhnya. Hal ini akan mempengaruhi pada pengujian pengusangan, karena struktur penting benih berhubungan langsung dengan kondisi deraan, baik uap panas ataupun etanol yang menyebabkan benih mati. Hal ini menunjukkan bahwa lama perendaman benih yang optimum untuk dikelupas adalah benih yang mengalami perendaman selama 24 jam. Hal ini selain optimum untuk pengelupasan, perendaman selama 24 jam akan mempersingkat waktu pengujian.

Tabel 1. Pengaruh perendaman benih kecipir menggunakan aquades dengan berbagai waktu perendaman terhadap jumlah benih yang dapat dikelupas testanya

\begin{tabular}{|c|c|c|c|c|c|c|c|c|}
\hline \multirow{2}{*}{$\begin{array}{c}\text { Waktu } \\
\text { perendaman } \\
\text { (jam) }\end{array}$} & \multicolumn{3}{|c|}{ Bisa dikupas (Benih) } & \multirow[b]{2}{*}{ Rata-rata } & \multicolumn{3}{|c|}{ Tidak bisa dikupas } & \multirow[b]{2}{*}{ Rata-rata } \\
\hline & U1 & $\mathrm{U} 2$ & U3 & & U1 & $\mathrm{U} 2$ & U3 & \\
\hline 12 & 6 & 7 & 7 & 7 & 19 & 18 & 18 & 18 \\
\hline 24 & 14 & 13 & 15 & 14 & 11 & 12 & 10 & 11 \\
\hline 36 & 17 & 20 & 19 & 19 & 8 & 5 & 6 & 6 \\
\hline
\end{tabular}

Hasil pewarnaan tetrazolium yang optimum adalah pewarnaan pada konsentrasi $0,3 \%$ dengan lama perendaman selama dua jam. Hal ini bisa terlihat dari Gambar 2 bahwa perendaman pada konsentrasi $0,1 \%$ dan $0,2 \%$ baik pada lama perendaman tetrazolium selama satu jam ataupun dua jam, serta konsentrasi $0,3 \%$ pada perendaman tetrazolium satu jam belum memberikan warna yang bagus yaitu merah cerah pada pengujian tetrazolium. Hal ini menunjukkan bahwa pada konsentrasi $0,3 \%$ dengan lama perendaman tetrazolium selama dua jam yang terpilih sebagai pewarnaan yang optimum pada pengujian berikutnya.

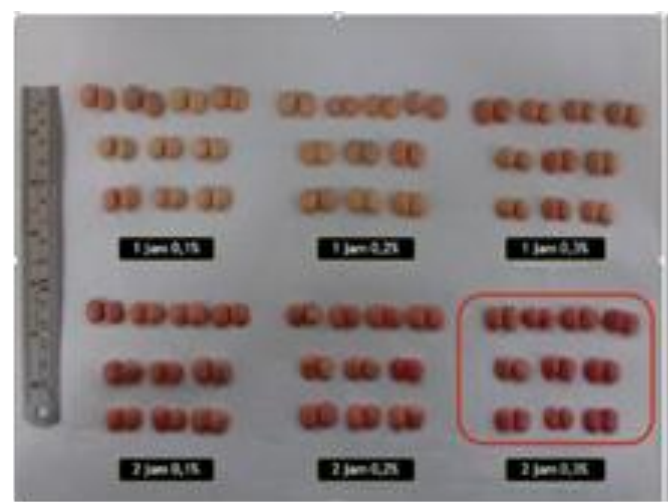

(a)

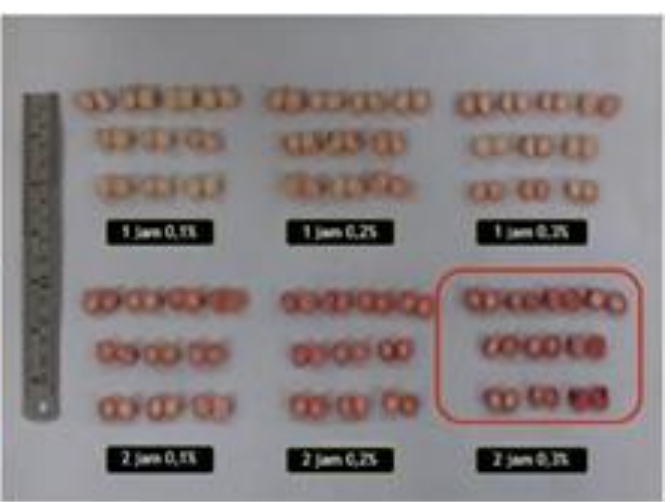

(b)

Gambar 2. Benih kecipir yang telah direndam dengan berbagai lama perendaman dan berbagai konsentrasi tetrazolium (a) struktur luar, (b) struktur dalam 
Pengusangan Benih Kecipir dengan Metode Fisik dan Kimia

Hasil percobaan menunjukkan bahwa pengusangan fisik dapat menurunkan potensi tumbuh maksimum dan berat kering kecambah normal namun tidak secara gradual. Pengusangan kimia dapat menurunkan daya berkecambah dan berat kering kecambah normal secara gradual (Tabel 2 dan 3).

Metode pengusangan cepat benih dipilih berdasarkan kemudahan pada saat pelaksanaan. Hasil percobaan menunjukkan bahwa pengusangan kimia lebih mudah pelaksanaannya dibandingkan pengusangan fisik. Hal ini dilihat dari pelaksanaan pengusangan fisik yang membutuhkan waktu cukup lama untuk mendapatkan suhu ruang deraan yang konstan yaitu sekitar 60-120 menit. Hal ini sejalan dengan penelitian Terryana et al. (2015) yang menyatakan bahwa pengusangan cepat kimia relatif lebih mudah dan lebih cepat dibandingkan dengan pengusangan secara fisik. Selain itu, pada peubah yang digunakan, peubah daya berkecambah dan berat kering kecambah normal yang paling menggambarkan viabilitas dibandingkan dengan potensi tumbuh maksimum. Hal ini sesuai dengan pernyataan Sadjad (1994) bahwa daya berkecambah dan berat kering kecambah normal merupakan peubah viabilitas potensial. Hal ini menunjukkan bahwa pengusangan kimia yang dipilih untuk percobaan selanjutnya. Waktu deraan yang dipilih dari pengusangan kimia adalah yang mempunyai nilai viabilitas yang berselang. Berdasarkan Tabel 3, waktu deraan yang mempunyai viabilitas berselang secara gradual adalah pada waktu penderaan $0 \times 5,2 \times 5,4 \times 5,6 \times 5$, dan $8 \times 5$ menit pada peubah DB.

Tabel 2. Pengaruh pengusangan fisik terhadap viabilitas benih kecipir

\begin{tabular}{|c|c|c|c|c|c|}
\hline \multirow{2}{*}{$\begin{array}{l}\text { Waktu Pengusangan } \\
\text { (menit) }\end{array}$} & \multicolumn{5}{|c|}{ Peubah } \\
\hline & $\mathrm{KA}(\%)$ & IV $(\%)$ & DB (\%) & PTM $(\%)$ & BKKN $(\%)$ \\
\hline 0 & 42,99 & $46,67 \mathrm{a}$ & $68,33 \mathrm{a}$ & $83,33 \mathrm{a}$ & $0,88 \mathrm{a}$ \\
\hline $1 \times 3$ & 49,10 & $43,33 \mathrm{a}$ & $60,00 \mathrm{ab}$ & $68,33 \mathrm{ab}$ & $0,69 \mathrm{ab}$ \\
\hline $2 \times 3$ & 42,33 & $26,67 \mathrm{bc}$ & $48,33 \mathrm{abc}$ & $75,00 \mathrm{ab}$ & $0,50 \mathrm{bc}$ \\
\hline $3 \times 3$ & 43,35 & $31,67 \mathrm{ab}$ & $60,00 \mathrm{ab}$ & $81,67 \mathrm{a}$ & $0,65 \mathrm{ab}$ \\
\hline $4 \times 3$ & 43,09 & $10,00 \mathrm{c}$ & $20,00 \mathrm{~d}$ & $30,00 \mathrm{~d}$ & $0,23 \mathrm{~cd}$ \\
\hline $5 \times 3$ & 44,65 & $23,33 \mathrm{bc}$ & $43,33 \mathrm{bcd}$ & $58,33 \mathrm{bc}$ & $0,47 \mathrm{bc}$ \\
\hline $6 \times 3$ & 39,96 & $15,00 \mathrm{bc}$ & $23,33 \mathrm{~d}$ & $40,00 \mathrm{~cd}$ & $0,26 \mathrm{~cd}$ \\
\hline $7 \times 3$ & 40,42 & $11,67 \mathrm{c}$ & $20,00 \mathrm{~d}$ & $40,00 \mathrm{~d}$ & $0,20 \mathrm{~d}$ \\
\hline $8 \times 3$ & 43,15 & $15,00 \mathrm{bc}$ & $25,00 \mathrm{~cd}$ & $43,33 \mathrm{~cd}$ & $0,26 \mathrm{~cd}$ \\
\hline $9 \times 3$ & 42,32 & $16,67 \mathrm{bc}$ & $31,67 \mathrm{~cd}$ & $58,33 \mathrm{bc}$ & $0,32 \mathrm{~cd}$ \\
\hline $\operatorname{Pr}>\mathrm{F}$ & $0,9380 \mathrm{tn}$ & $0,0006^{*}$ & $0,0005 *$ & $0,0001 * *$ & $0,0001 * *$ \\
\hline $\mathrm{KK}(\%)$ & 16,71 & $19,61 * *)$ & $17,81 *)$ & 18,85 & $7,59 *)$ \\
\hline
\end{tabular}

Keterangan : Angka yang diikuti huruf berbeda pada kolom yang sama berbeda nyata berdasarkan hasil Duncan's multiple range test (DMRT) pada taraf $\alpha=5 \%$, KA : kadar air, IV : indeks vigor, DB : daya berkecambah, PTM : potensi tumbuh maksimum, BKKN : berat kering kecambah normal, * : nyata, ** : sangat nyata, *) : data ditransformasikan ke $\sqrt{ } \mathrm{x}+0.5, * *)$ : data ditransformasi ke $\sqrt{ } \mathrm{x}+1$

Tabel 3. Pengaruh pengusangan kimia terhadap viabilitas benih kecipir

\begin{tabular}{|c|c|c|c|c|c|}
\hline \multirow{2}{*}{$\begin{array}{l}\text { Waktu Pengusangan } \\
\text { (menit) }\end{array}$} & \multicolumn{5}{|c|}{ Peubah } \\
\hline & KA $(\%)$ & IV $(\%)$ & DB (\%) & PTM $(\%)$ & BKKN (\%) \\
\hline 0 & 39,83 & $48,33 \mathrm{a}$ & $76,67 \mathrm{a}$ & 86,67 & $0,97 \mathrm{a}$ \\
\hline $1 \times 5$ & 41,44 & $31,67 \mathrm{ab}$ & $60,00 \mathrm{~b}$ & 90,00 & $0,70 \mathrm{~b}$ \\
\hline $2 \times 5$ & 46,79 & $28,33 \mathrm{bc}$ & $53,33 \mathrm{bc}$ & 80,00 & $0,63 \mathrm{bc}$ \\
\hline $3 \times 5$ & 39,75 & $31,67 \mathrm{ab}$ & $51,67 \mathrm{bc}$ & 86,67 & $0,53 \mathrm{bcd}$ \\
\hline $4 \times 5$ & 38,32 & $26,67 \mathrm{bc}$ & $46,67 \mathrm{bcd}$ & 88,33 & 0,44 cde \\
\hline $5 \times 5$ & 45,37 & $16,67 \mathrm{bcd}$ & $46,67 \mathrm{bcd}$ & 83,33 & 0,47 cde \\
\hline $6 \times 5$ & 46,45 & $16,67 \mathrm{bcd}$ & $38,33 \mathrm{~cd}$ & 73,33 & $0,37 \mathrm{de}$ \\
\hline $7 \times 5$ & 46,04 & $10,00 \mathrm{~cd}$ & $31,67 \mathrm{de}$ & 73,33 & 0,29 ef \\
\hline $8 \times 5$ & 41,90 & $6,67 \mathrm{~d}$ & 16,67 ef & 80,00 & $0,12 \mathrm{f}$ \\
\hline $9 \times 5$ & 45,99 & $1,67 \mathrm{~d}$ & $13,33 \mathrm{f}$ & 78,33 & $0,11 \mathrm{f}$ \\
\hline $\operatorname{Pr}>F$ & $0,5955 \mathrm{tn}$ & $0,0008 *$ & $<, 0001 * *$ & $0,4510 \mathrm{tn}$ & $<, 0001 * *$ \\
\hline $\mathrm{KK}(\%)$ & 14,33 & $19,64 * * *)$ & $14,82 *)$ & 12,40 & $5,62 *)$ \\
\hline
\end{tabular}

Keterangan : Angka yang diikuti huruf berbeda pada kolom yang sama berbeda nyata berdasarkan hasil Duncan's multiple range test (DMRT) pada taraf $\alpha=5 \%$, KA : kadar air, IV : indeks vigor, DB : daya berkecambah, PTM : potensi tumbuh maksimum, BKKN : berat kering kecambah normal, * : nyata, ** : sangat nyata, *) : data ditransformasikan ke $\sqrt{ } \mathrm{x}+0.5, * *)$ : data ditransformasi ke $\sqrt{ } \mathrm{x}+5,5$ 


\section{Pembuatan Pola Pewarnaan pada Benih Kecipir}

Percobaan pembuatan pola menghasilkan

15 pewarnaan benih yang terbentuk. Pewarnaan tersebut kemudian dikelompokkan menggunakan standar yang membedakan benih menjadi kecambah normal kuat, normal, abnormal, dan mati sebanyak tiga pola, yaitu pola 1 , pola 2 , dan pola 3 seperti tertera pada gambar 3, 4, dan 5 .

Kriteria pola 1 atau disebut juga dengan pola kriteria ketat mempunyai kriteria sebagai berikut :

a. Normal kuat : Poros embrio serta kotiledon permukaan dalam dan luar berwarna merah terang.

b. Normal : Poros embrio dan kotiledon permukaan dalam berwarna merah terang, kotiledon permukaan luar terdapat warna merah gelap kurang dari $25 \%$., Poros embrio berwarna merah terang, kotiledon permukaan dalam dan luar terdapat warna merah gelap kurang dari $25 \%$, Poros embrio dan kotiledon permukaan luar berwarna merah terang, kotiledon permukaan dalam terdapat warna putih kurang dari 25\%, Poros embrio dan kotiledon permukaan luar berwarna merah terang, kotiledon permukaan dalam terdapat warna putih kurang dari $25 \%$.

c. Abnormal : Poros embrio berwarna merah terang, kotiledon permukaan luar terdapat warna merah gelap kurang dari $25 \%$, kotiledon permukaan dalam terdapat warna putih lebih dari 25\%, Poros embrio dan kotiledon permukaan luar berwarna merah cerah, kotiledon permukaan dalam terdapat warna putih atau merah gelap lebih dari $25 \%$, Poros embrio terdapat warna merah gelap kurang dari $25 \%$, kotiledon permukaan luar berwarna merah cerah, kotiledon permukaan dalam terdapat warna putih lebih dari $25 \%$, Poros embrio terdapat warna merah gelap kurang dari $25 \%$, kotiledon permukaan luar berwarna merah cerah, kotiledon permukaan dalam terdapat warna putih lebih dari $25 \%$.

d. Mati : Poros embrio berwarna merah gelap kurang dari $50 \%$, kotiledon permukaan luar terdapat warna merah gelap kurang dari $25 \%$, kotiledon permukaan dalam berwarna merah cerah, Poros embrio berwarna merah gelap lebih dari 50\%, kotiledon permukaan luar berwarna merah cerah, kotiledon permukaan dalam terdapat warna putih lebih dari $25 \%$, Poros embrio seluruhnya berwarna merah gelap, kotiledon permukaan luar dan dalam berwarna merah cerah, Poros embrio seluruhnya berwarna merah gelap, kotiledon permukaan luar dan dalam terdapat warna merah gelap kurang dari $25 \%$, Poros embrio seluruhnya berwarna merah gelap, kotiledon permukaan luar dan dalam terdapat warna merah gelap lebih dari 25\%, Poros embrio seluruhnya berwarna merah gelap, kotiledon permukaan luar dan dalam terdapat warna merah gelap lebih dari $50 \%$.

Kriteria pola 2 atau disebut juga dengan pola kriteria medium mempunyai kriteria sebagai berikut :

a. Normal kuat : Poros embrio serta kotiledon permukaan dalam dan luar berwarna merah terang, Poros embrio dan kotiledon permukaan dalam berwarna merah terang, kotiledon permukaan luar terdapat warna merah gelap kurang dari 25\%., Poros embrio berwarna merah terang, kotiledon permukaan dalam dan luar terdapat warna merah gelap kurang dari $25 \%$, Poros embrio dan kotiledon permukaan luar berwarna merah terang, kotiledon permukaan dalam terdapat warna putih kurang dari $25 \%$.

b. Normal : Poros embrio dan kotiledon permukaan luar berwarna merah terang, kotiledon permukaan dalam terdapat warna putih kurang dari $25 \%$, Poros embrio berwarna merah terang, kotiledon permukaan luar terdapat warna merah gelap kurang dari $25 \%$, kotiledon permukaan dalam terdapat warna putih lebih dari 25\%, Poros embrio dan kotiledon permukaan luar berwarna merah cerah, kotiledon permukaan dalam terdapat warna putih atau merah gelap lebih dari $25 \%$.

c. Abnormal : Poros embrio terdapat warna merah gelap kurang dari $25 \%$, kotiledon permukaan luar berwarna merah cerah, kotiledon permukaan dalam terdapat warna putih lebih dari $25 \%$, Poros embrio terdapat warna merah gelap kurang dari $25 \%$, kotiledon permukaan luar berwarna merah cerah, kotiledon permukaan dalam terdapat warna putih lebih dari $25 \%$, Poros embrio berwarna merah gelap kurang dari $50 \%$, kotiledon permukaan luar terdapat warna merah gelap kurang dari $25 \%$, kotiledon permukaan dalam berwarna merah cerah, Poros embrio berwarna merah gelap lebih dari $50 \%$, kotiledon permukaan luar berwarna merah cerah, kotiledon permukaan dalam terdapat warna putih lebih dari $25 \%$.

d. Mati : Poros embrio seluruhnya berwarna merah gelap, kotiledon permukaan luar dan dalam berwarna merah cerah, Poros embrio seluruhnya berwarna merah gelap, kotiledon permukaan luar dan dalam terdapat warna merah gelap kurang dari $25 \%$, Poros embrio seluruhnya berwarna merah gelap, kotiledon permukaan luar dan dalam terdapat warna 
merah gelap lebih dari $25 \%$, Poros embrio seluruhnya berwarna merah gelap, kotiledon permukaan luar dan dalam terdapat warna merah gelap lebih dari $50 \%$.

Kriteria pola 3 atau disebut juga dengan pola kriteria luas mempunyai kriteria sebagai berikut :

a. Normal kuat : Poros embrio serta kotiledon permukaan dalam dan luar berwarna merah terang, Poros embrio dan kotiledon permukaan dalam berwarna merah terang, kotiledon permukaan luar terdapat warna merah gelap kurang dari 25\%., Poros embrio berwarna merah terang, kotiledon permukaan dalam dan luar terdapat warna merah gelap kurang dari $25 \%$, Poros embrio dan kotiledon permukaan luar berwarna merah terang, kotiledon permukaan dalam terdapat warna putih kurang dari 25\%, Poros embrio dan kotiledon permukaan luar berwarna merah terang, kotiledon permukaan dalam terdapat warna putih kurang dari $25 \%$.

b. Normal : Poros embrio berwarna merah terang, kotiledon permukaan luar terdapat warna merah gelap kurang dari $25 \%$, kotiledon permukaan dalam terdapat warna putih lebih dari 25\%, Poros embrio dan kotiledon permukaan luar berwarna merah cerah, kotiledon permukaan dalam terdapat warna putih atau merah gelap lebih dari $25 \%$, Poros embrio terdapat warna merah gelap kurang dari $25 \%$, kotiledon permukaan luar berwarna merah cerah, kotiledon permukaan dalam terdapat warna putih lebih dari $25 \%$, Poros embrio terdapat warna merah gelap kurang dari $25 \%$, kotiledon permukaan luar berwarna merah cerah, kotiledon permukaan dalam terdapat warna putih lebih dari $25 \%$.

c. Abnormal : Poros embrio berwarna merah gelap kurang dari $50 \%$, kotiledon permukaan luar terdapat warna merah gelap kurang dari $25 \%$, kotiledon permukaan dalam berwarna merah cerah, Poros embrio berwarna merah gelap lebih dari $50 \%$, kotiledon permukaan luar berwarna merah cerah, kotiledon permukaan dalam terdapat warna putih lebih dari $25 \%$, Poros embrio seluruhnya berwarna merah gelap, kotiledon permukaan luar dan dalam berwarna merah cerah.

a. Mati : Poros embrio seluruhnya berwarna merah gelap, kotiledon permukaan luar dan dalam terdapat warna merah gelap kurang dari $25 \%$, Poros embrio seluruhnya berwarna merah gelap, kotiledon permukaan luar dan dalam terdapat warna merah gelap lebih dari $25 \%$, Poros embrio seluruhnya berwarna merah gelap, kotiledon permukaan luar dan dalam terdapat warna merah gelap lebih dari $50 \%$.

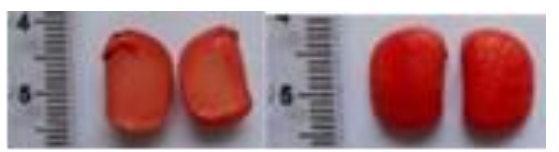

(a)

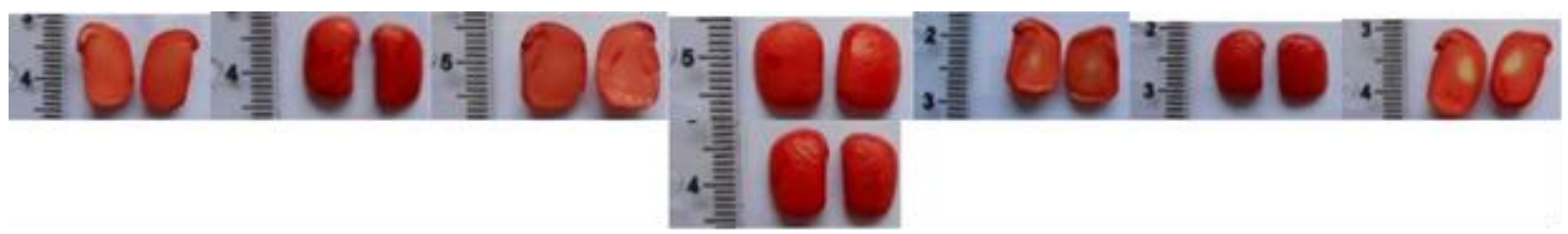

(b)

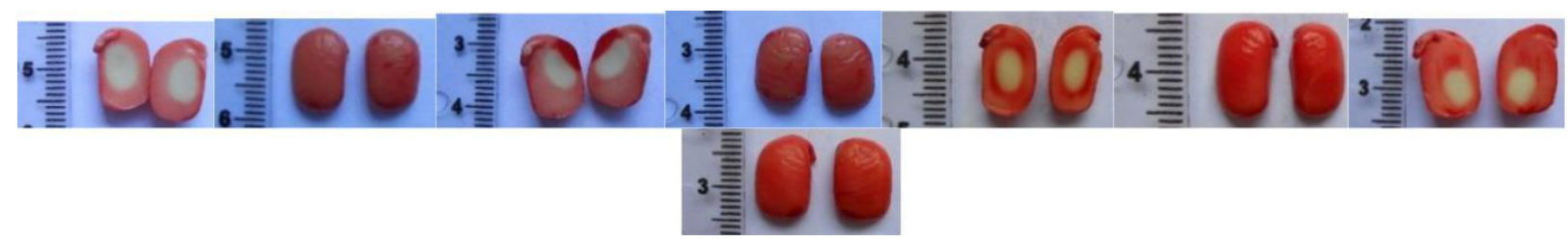

(c)

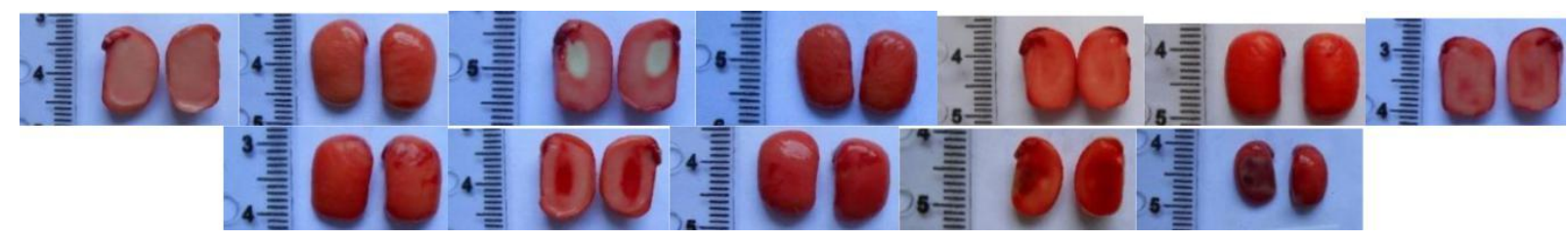

(d)

Gambar 3. Pola pewarnaan tetrazolium pola 1, kriteria kecambah (a) normal kuat, (b) normal, (c) abnormal dan (d) mati 
Bul. Agrohorti 6 (2) : 231-240 (2018)

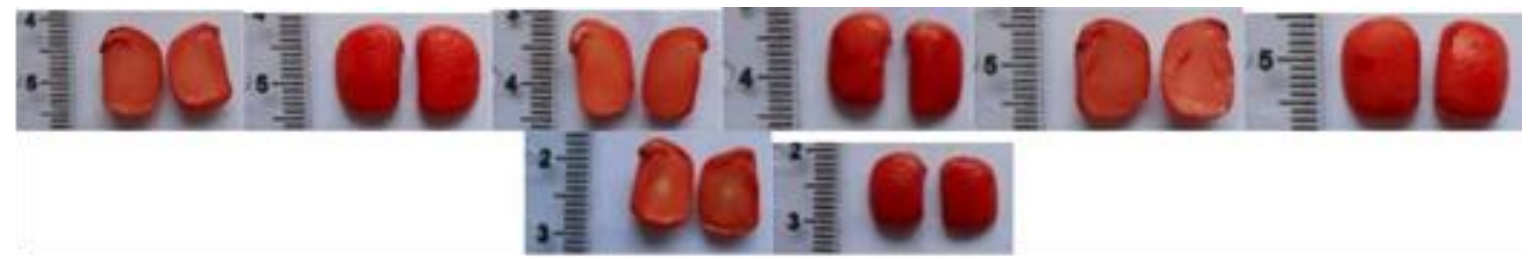

(a)

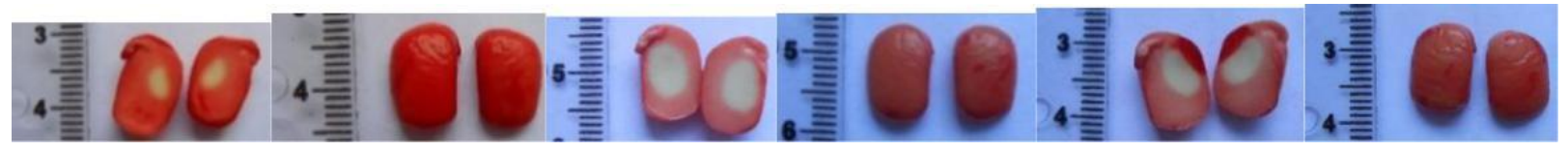

(b)

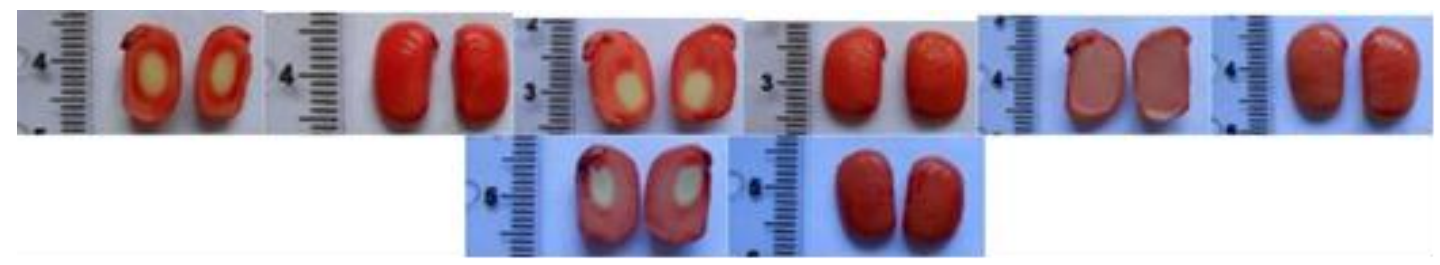

(c)

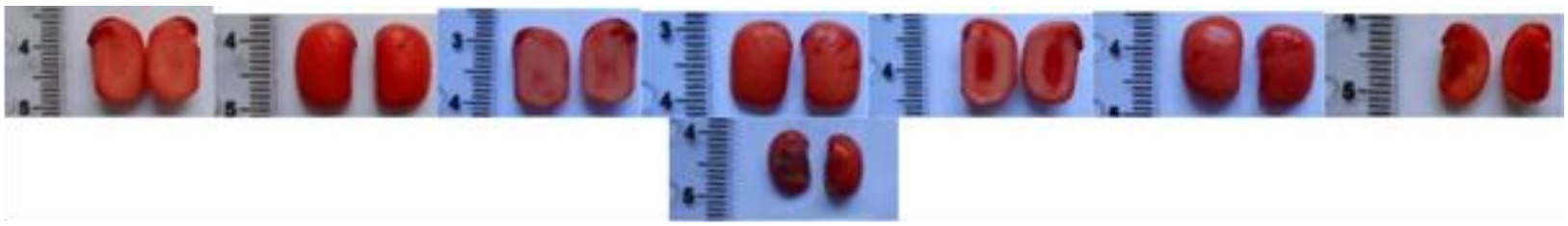

(d)

Gambar 4. Pola pewarnaan tetrazolium pola 2, kriteria kecambah (a) normal kuat, (b) normal, (c) abnormal dan (d) mati

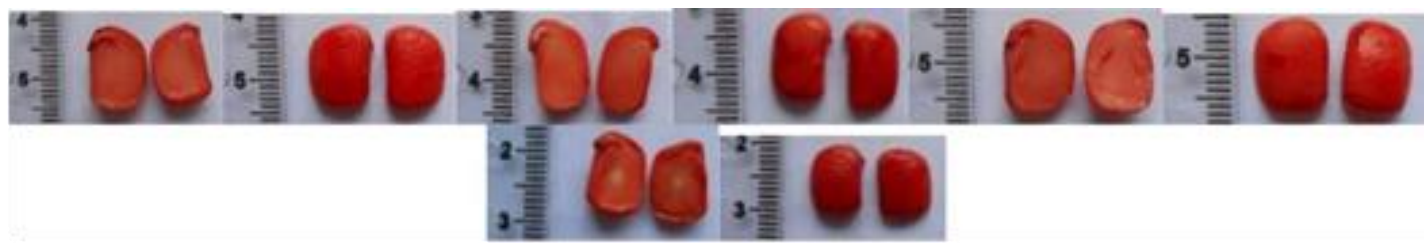

(a)

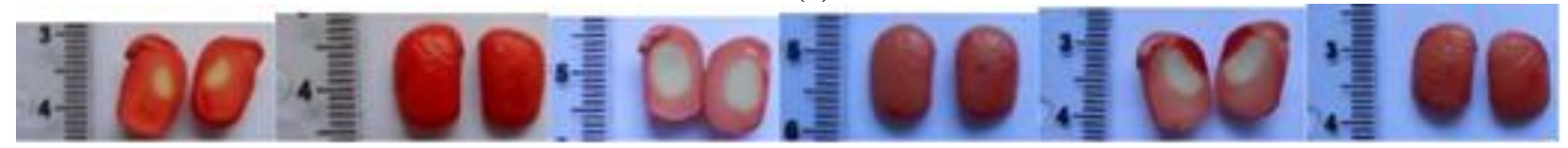

(b)

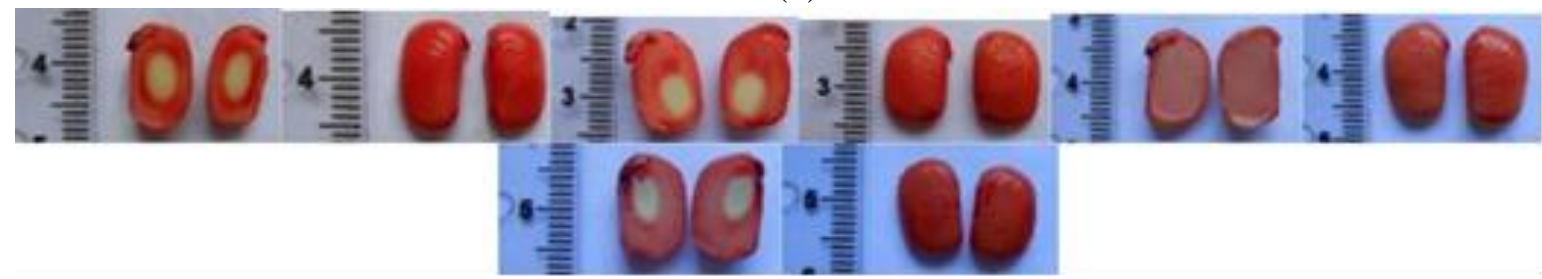

(c)

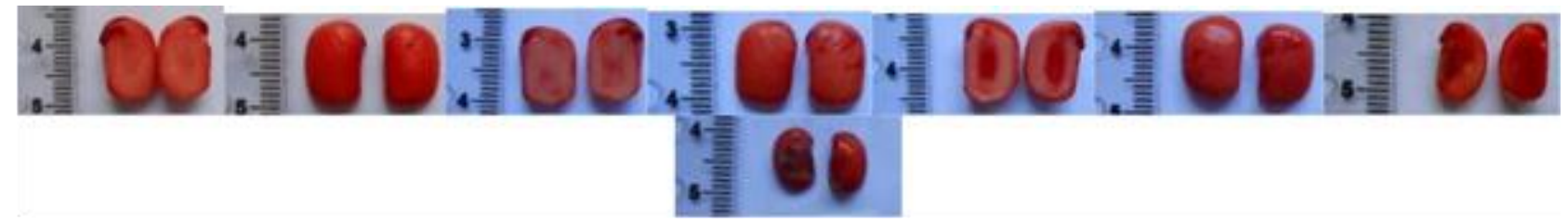

(d)

Gambar 5. Pola pewarnaan tetrazolium pola 3, kriteria kecambah (a) normal kuat, (b) normal, (c) abnormal dan (d) mati 


\section{Pengujian Pola Pewarnaan pada Benih Kecipir}

Tabel 4 berfungsi untuk mengetahui kecenderungan garis dan keeratan hubungan pola pewarnaan tolok ukur tetrazolium terhadap tolok ukur fisiologi dengan menentukan besarnya selisih nilai koefisien regresi yang menghubungkan antara pengusangan sebagai sumbu x dan viabilitas (tetrazolium dan fisiologi) sebagai sumbu y pada setiap persamaan regresi yang terbentuk. Berdasarkan Tabel 4 dapat dilihat bahwa nilai selisih yang paling kecil (kurang dari 1) pada peubah $\mathrm{DB}$ adalah pola 3 dengan nilai 0.95. Nilai selisih paling kecil pada peubah IV tidak ada, sedangkan pada peubah PTM selisih paling kecil terdapat pada semua pola.

Tabel 4. Selisih nilai koefisien regresi antara tolok ukur tetrazolium dengan tolok ukur fisiologi

\begin{tabular}{cccl}
\hline Pola & DB & IV & PTM \\
\hline 1 & 1,12 & 1,03 & 0,21 \\
2 & 1,05 & 1,08 & 0,41 \\
3 & 0,95 & 1,08 & 0,49 \\
\hline
\end{tabular}

Keterangan : Pengusangan (sumbu $\mathrm{x}$ ) dan viabilitas benih (sumbu y)

Tabel 5 berfungsi untuk melihat kesamaan antara tolok ukur tetrazolium dengan tolok ukur fisiologi dengan mengetahui nilai koefisien regresi yang menghubungkan antara tolok ukur tetrazolium (sumbu $\mathrm{x}$ ) dengan tolok ukur fisiologi (sumbu y). Berdasarkan Tabel 5 tampak bahwa nilai koefisien regresi tidak nyata pada semua peubah, tapi nilai koefisien regresi satu atau mendekati satu pada peubah DB adalah pola 2 dan pola 3 , pada peubah IV tidak ada, sedangkan pada peubah PTM adalah pola 1 dan pola 2.

Tabel 5. Nilai koefisien regresi antara tolok ukur tetrazolium dengan tolok ukur fisiologi

\begin{tabular}{cccc}
\hline Pola & DB & IV & PTM \\
\hline 1 & $0,02 \mathrm{tn}$ & $3,50 \mathrm{tn}$ & $0,72 \mathrm{tn}$ \\
2 & $1,71 \mathrm{tn}$ & $0,06 \mathrm{tn}$ & $1,00 \mathrm{tn}$ \\
3 & $1,88 \mathrm{tn}$ & $-2,25 \mathrm{tn}$ & $0,11 \mathrm{tn}$ \\
\hline
\end{tabular}

Keterangan : Tolok ukur tetrazolium (sumbu x) dan tolok ukur fisiologi (sumbu y)

Tabel 6 berfungsi untuk mengetahui keeratan hubungan antara tolok ukur tetrazolium dengan tolok ukur fisiologi. Berdasarkan Tabel 6 tampak bahwa nilai koefisien korelasi tidak nyata pada semua peubah, tapi nilai koefisien korelasi satu atau mendekati satu pada peubah DB adalah pola 2 dan pola 3 , pada peubah IV adalah pola 1 , dan pada peubah PTM adalah pola 1 dan pola 2 .
Tabel 6. Nilai koefisien korelasi antara tolok ukur tetrazolium dengan tolok ukur fisiologi

\begin{tabular}{cccc}
\hline Pola & DB & IV & PTM \\
\hline 1 & $0,01 \mathrm{tn}$ & $0,41 \mathrm{tn}$ & $0,64 \mathrm{tn}$ \\
2 & $0,50 \mathrm{tn}$ & $0,02 \mathrm{tn}$ & $0,45 \mathrm{tn}$ \\
3 & $0,62 \mathrm{tn}$ & $-0,30 \mathrm{tn}$ & $0,06 \mathrm{tn}$ \\
\hline Keterangan : & Tolok ukur tetrazolium (sumbu x) & dan tolok \\
& ukur fisiologi (sumbu y) &
\end{tabular}

Berdasarkan Tabel 4, 5, dan 6, pola yang sering muncul pada ketiga tabel di atas adalah pola 3 pada peubah DB namun tidak secara nyata. Menurut Sadjad (1994) daya berkecambah merupakan peubah viabilitas potensial.

\section{KESIMPULAN}

Percobaan pertama memperoleh waktu perendaman aquades yang efektif pada benih kecipir yaitu 24 jam, memperoleh konsentrasi tetrazolium yang efektif yaitu $0,3 \%$, memperoleh waktu perendaman tetrazolium yang efektif yaitu dua jam. Percobaan kedua memperoleh metode pengusangan, yaitu pengusangan secara kimia dan dipilih 5 waktu penderaan yang menghasilkan viabilitas secara gradual yaitu $0 \times 5,2 \times 5,4 \times 5,6 \times 5$, dan $8 \times 5$ menit. Percobaan ketiga pola pewarnaan pada embrio benih kecipir belum bisa digunakan untuk mengevaluasi viabilitas benih kecipir karena diduga kriteria pola yang dibuat terlalu sempit.

\section{DAFTAR PUSTAKA}

Copeland, L.O., M.B. McDonald. 2001. Principles of Seed Science and Technology $4^{\text {th }}$ Edition. London (US) : Kluwer Academic Publishers.

Dina, E. Widajati, B. Wiryawan, S. Ilyas. 2007. Pola topografi pewarnaan tetrazolium sebagai tolok ukur viabilitas dan vigor benih kedelai (Glycine max L.Merr.) untuk pendugaan pertumbuhan tanaman di lapangan. Bul. Agron. 35(2):88-95.

Gomez, K.A., A.A. Gomez. 1995. Prosedur Statistika untuk Penelitian Pertanian. Jakarta (ID): UI Press.

Handayani, T. 2013. Kecipir (Psophocarpus tetragonolobus L.) potensi lokal yang terpinggirkan. Balai Penelitian Tanaman Sayur. Bandung.

ISTA. 2014. International Rules for Seed Testing. ISTA. Switzerland. 
Krisnawati, A. 2010. Keragaman genetik dan potensi pengembangan kecipir (Psophocarpus tetragonolobus L.) di Indonesia. Jurnal Litbangtan. 29(3):118.

Sadjad, S. 1994. Kuantifikasi Metabolisme Benih. Jakarta (ID): PT Gramedia.
Terryana, R.T., M.R. Suhartanto, A. Qadir. 2015. Alat pengusang cepat IPB 77-1 MM untuk penapisan vigor daya simpan benih kedelai. 34(3):232.

Widajati, E., E. Murniati, E.R. Palupi E.R., T.K. Suharsi, M.R. Suhartanto, A. Qadir. 2013. Dasar Ilmu dan Teknologi Benih. Bogor (ID): IPB Press. 173 hal. 